\title{
Símbolos de poder y su expresión en el mundo urbano del siglo Xvl: la villa de Talavera y su señor el arzobispo de Toledo
}

\author{
César Pacheco Jiménez *
}

\begin{abstract}
RESUMEN ABSTRACT
En la España de la primera mitad del siglo XVI subsisten instituciones y relaciones de poder heredadas de la Edad Media. En el ámbito local éstas pueden rastrearse de manera más clara y concisa, sobre todo cuando se trata de lugares sometidos a un régimen señorial nobiliario 0 eclesiástico. El caso de Talavera de la Reina (Toledo), responde al segundo modelo; propiedad de los arzobispos toledanos desde 1369, cuando Enrique II le concede la villa y su tierra a Gómez Manrique, que entonces ostentaba la mitra en la archidiócesis, Talavera pretenderá a lo largo de tiempo conservary defender sus privilegios $y$ costumbres forjadas en la etapa en que fuera villa de realengo. Las especiales condiciones en la

During the first half of the Sixteenth Century there existed institutions and power relations in Spain that had been originated in the Middle Age. These institutions can be well documented at a local level, especially in places under manorial dominion. The case of Talavera de la Reina, in Toledo, constitutes a good example to study the expressions and the symbols of power implemented by the town council to maintain its old privileges and customs of its royal jurisdictional past, given that it fell under ecclesiastical dominion in 1369. This Study shows expressions and formulas of a feudal nature - such as homageexhibited by those in power in the Early Modern period.
\end{abstract}

* UNED. 
relación del concejo con su señor se

mantienen en la centuria

decimoquinta, de tal manera que ante una nueva ocupación de la

sede toledana, la villa y sus representantes ponian en marcha las expresiones político-simbólicas

del homenaje y demás fórmulas feudovasalláticas. Este aparato de demostración alcanzaba también la transformación temporal de ciertos

elementos del espacio urbano.

En nuestro trabajo intentamos analizar este hecho para aportar nuevos datos en el conocimiento del funcionamiento de las ciudades $y$ villas en el campo institucional y sus condicionantes históricos.

\section{INTRODUCCIÓN}

El 21 de septiembre de 1558 moría en el Monasterio Jerónimo de Yuste, enclavado en un paraje de gran belleza paisajística, el hombre que habia conducido a una gran parte del territorio occidental bajo un mismo mando imperial. El rey Carlos I en España y el $V$ de Alemania, emperador, yacía tras unas horas de agonía, consumido por la gota. Entre los que acompañaron al monarca en sus últimos momentos junto al lecho, se encontraba el polémico fraile dominico y recientemente nombrado arzobispo de Toledo, fray Bartolomé de Carranza y Miranda 1. Había llegado a Yuste el día anterior y tras presentarse delante del moribundo, éste le había preguntado por los asuntos de los herejes de $\mathrm{Va}$ lladolid, a lo que respondió, se supone que tratando de esquivar el tema: "No se trata ahora de otra cosa, sino de la salud de vuestra majestad" 2 .

Sobre Carranza pueden consultarse las siguientes obras: P. SALAZAR DE MENDOzA: Vida y sucesos prósperos y adversos de don Fr. Bartolorné de Carranza y Miranda. Madrid, Imp. Joseph Doblado, 1788. Y J. Ignacio Tellechea Idigoras: El Arzobispo Carranza y su tiempo. Madrid, Guadarrama, 1968. 2 vol. Marcel Bataillon, Erasmo y España. Estudios sobre la historia espiritual del siglo xvi. Madrid, 1991; pp. 705-714.

2 Joseph Pérez, Carlos V. Madrid, Temas de Hoy, 1999, p. 244. 
El recelo y desconfianza que surgieron en el emperador en sus últimos tiempos contra Carranza eran fruto de las advertencias que la propia princesa doña Juana le había hecho, auspiciadas por el inquisidor general Valdés. La publicación de su obra Comentarios del Cathecismo Cristiano (Amberes, 1558) le había granjeado a Carranza profundas sospechas, además se le acusaba de mantener estrechas relaciones con acusados de herejía. El ambiente se enrareció aun más, cuando el arzobispo tuvo que coincidir en Yuste con fray Juan Regla, confesor del ex emperador, y enemigo de Carranza desde 1551 y el Concilio de Trento; no en vano, a la larga esa enemistad acarrearía unas consecuencias negativas para el prelado toledano, cuando Regla se presenta el 9 de diciembre de 1558 a declarar contra él en Valladolid, manifestando sus planteamientos luteranos ante la muerte, e invalidando el sacramento de la confesión en las últimas horas del rey en Yuste ${ }^{3}$. Todos los testigos declararon posteriormente que la actitud de Carranza en el trance de la muerte les había parecido sumamente sospechosa e incluso escandalosa. De esta manera, como dice Joseph Pérez, la muerte del emperador iba a desatar una de las crisis más serias de la España de la segunda mitad del siglo xvı.

Considerar el proceso de la Inquisición contra el religioso dominico no es motivo de esta comunicación, pero si lo esbozamos por suponer un acontecimiento de gran relevancia como coyuntura en la que se mueve nuestro personaje, el arzobispo Carranza. Como prelado toledano y señor de la villa de Talavera de la Reina, su vinculación con el augusto César ofrece si cabe un mayor atractivo; una figura que cumpliendo con sus obligaciones como religioso, como responsable de la más poderosa archidiócesis de la España del siglo xvI, y como persona próxima, en sus primeros momentos al rey sucesor, Felipe II, tuvo sin embargo que padecer y sufrir uno de los procesos más emblemáticos de la institución inquisitorial; en él se constatan otras implicaciones de tensión entre la Iglesia y el Estado ${ }^{4}$.

\footnotetext{
3 Todos los acontecimientos que ocurrieron en la cámara del monarca en Yuste fueron después utilizados en el proceso inquisitorial de Carranza. Detalles y pormenores de este asunto los tenemos en la clásica obra de Marcelino Menéndez y Pelayo, Historia de los $\mathrm{He}$ torodoxos Españoles 11: Protestantismo y sectas misticas. Regalismo y Enciclopedia. Heterodoxia en el siglo xix. Madrid, B.A.C., 1982.

4 J. Ignacio Tellechea loigoras: "El proceso del arzobispo Carranza, "test" de las tensiones Iglesia-Estado" en La Inquisición Española. Nueva visión, nuevos horizontes. Madrid, Siglo XXI, 1980 , pp. $69-82$
} 
El arzobispo de hallaba hasta julio de 1557 en Inglaterra por una comisión real del rey Felipe en asuntos religiosos. En esas fechas se traslada a Flandes donde llevará a cabo una labor de predicación, pesquisas de herejes y destrucción de libros, y toda una serie de indagaciones para delatar a españoles sospechosos de herejía, lo que le valió la confianza del monarca. A principios del 1558 se encontraba ya en Bruselas 5 . Unos meses antes había muerto don Juan Martínez Silíceo dejando vacante la sede toledana ${ }^{6}$. Felipe II nombró inmediatamente a Carranza como sucesor del prelado, siendo preconizado en consistorio el 16 de diciembre de 1557. La propuesta fue aceptada sin ningún tipo de duda por el pontífice Pablo IV dada la reputación de celo y servicio del candidato.

El 27 de febrero de 1558 fue consagrado en Bruselas por el cardenal Granvela, mientras que la posesión de la mitra toledana la hacian en su nombre el canónigo de Palencia Pedro de Mérida y el consejero de Castilla D. Diego Briviesca de Muñatones, el 8 de marzo ${ }^{7}$. Quedaba como gobernador del arzobispado hasta la ida de Carranza, el canónigo Mérida ${ }^{8}$. Esto significaba, como en otras ocasiones, que la dirección de la archidiócesis quedaba en manos de delegados que asumían funciones a todos los niveles, incluso las propias del régimen señorial que los prelados toledanos tenían sobre algunos territorios de la diócesis. Esta vertiente es la que queremos analizar aqui, exponiendo en el caso de Carranza y su delegado directo Briviesca de Muñatones, un ejemplo de relaciones feudovasalláticas entre el arzobispo, como señor de la villa y su tierra, y el concejo de Talavera, en pleno siglo XVI.

\section{TALAVERA, VILLA DE SEÑORIOO JURISDICCIONAL}

La formación y consolidación de la villa y tierra de Talavera durante la Edad Media vinieron acompañadas de la pérdida progresiva de parte

5 El 15 de enero de 1558 firmaba en Bruselas un poder para el licenciado Briviesca de Muñatones para la posesión de la villa de Talavera.

6 VV.AA.: Los Primados de Toledo. Toledo, 1993, pp. 106-107.

Menéndez y Pelayo, op. cit., II, p. 10-11.

- Menéndez Pelayo considera que el canónigo Mérida quedaba como gobernador general del arzobispado, sin embargo, por la documentación que hemos consultado, es Briviesca de Muñatones el que aparece con este cargo en estos primeros momentos de la prelatura de Carranza. 
de su amplio territorio fruto de las desmembraciones que la corona iba haciendo a favor de personajes de la corte que ganaron la confianza de los monarcas, creándose así un mosaico de condados, marcas y señoríos en el entorno del alfoz talaverano ${ }^{9}$. De tal manera que en el siglo XIV la tierra talaverana se extendía desde los montes al norte de la villa y del Tajo, hasta los confines meridionales en la tierra de Castilblanco ${ }^{10}$, Valdecaballeros y lindes con la Puebla de Santa María de Guadalupe, otro dominio señorial creado en $1348{ }^{11}$. En la etapa del reinado del emperador Carlos, la villa vivía pues rodeada de varios ámbitos señoriales en los que los intereses de la nobleza laica pugnaban en ocasiones con los del señorío eclesiástico de Talavera, fenómeno que será especialmente virulento con el de Mejorada, regido primero por el linaje de los López de Toledo y luego por la Casa y Condado de Oropesa ${ }^{12}$.

Todo este vasto territorio respondía a una realidad geográfica e histórica que necesitó de un modelo repoblador sometida a una precariedad y lentitud predominante, al menos hasta finales del siglo $x v$ que se pone en marcha una tardía campaña de creación de nuevos asentamientos en el sector sur del Tajo, conocido por la comarca de la Jara.

Talavera, villa de realengo había pertenecido en determinados períodos a las reinas, entre ellas a doña María de Portugal, esposa de Alfonso XI, que le valió el apellido que actualmente ostenta. Pero las concesiones y mercedes en tiempo de Enrique II acabaron con esta titularidad real; el rey, en pago a los servicios y apoyos recibidos por el arzobispo Gómez Manrique en la contienda civil con su hermanastro

9 Sobre la evolución de Talavera y su tierra en la Edad Media vid. Enrique Rodriguez-P!cavea Matilla, La Villa y la Tierra de Talavera en la Plena Edad Media. Orígenes, consolidación y crecimientos de un concejo de realengo (siglos Xi-XiII). Talavera, 1996. M. a Jesús SuÁrez Alvarez: La Villa de Talavera y su Tierra en la Edad Media (1369-1504). Oviedo, 1982. José Gómez Menor: La antigua tierra de Talavera. Bosquejo histórico y aportación documental. Toledo, 1965.

10 Precisamente Castilblanco, Alía y Valdecaballeros intentarán bajo el reinado de Carlos y luego Felipe II la desvinculación de la tierra de Talavera, consiguiendo un privilegio de Carlos I en 1556 declarando villa a Castilblanco (Juan Rodríguez PASTOR, "Castilblanco en la antigua tierra de Talavera" en Cuaderna, n. ${ }^{\circ} 6$ (Talavera, 1998), pp. 62-78.

11 J. Carlos VIZUETE MENDOZA, La formación de un gran dominio en la tierra de Talavera: Santa Maria de Guadalupe (Estudio y regesta 1340-1389). Talavera, 1993.

12 César PACHECo (coordinador): Mejorada. Historia de una villa de señorio. Talavera, 2000. Sobre el resto de ambitos señoriales de la zona talaverana, véase la obra de Salvador de Moxó, Los antiguos señorios de Toledo. Toledo, 1973. 
Pedro I, le concede el señorío jurisdiccional y posesión plena de las villas de Talavera e Illescas, a cambio de la villa de Alcaraz que era propiedad arzobispal ${ }^{13}$.

Lógicamente, las condiciones de la concesión real establecían el pleno derecho de un señorío jurisdiccional sobre todo el alfoz y la tierra de Talavera, con las atribuciones señoriales y feudales propias de la época: "damos vos en donaçión pura, para agora e para siempre jamas, para vos e para la vuestra eglesia e para la mesa arçobispal et para los otros arçobispos que despues de uos fueren de la dicha eglesia, la nuestra villa de Talauera, con todas sus aldeas e con todos sus términos poblados e por poblar, e con todos los castiellos e fortalezzas d'ella e de sus terminos, e con todas las rrentas e pechos e derechos de la dicha villa...e con la justiçia çeuil e criminal e alçadas e mero mixto imperio e con la juridiçión alta e baxa e con el sennorio de la dicha villa e de sus terminos...».

Así pues, desde 1369, el destino de Talavera irá unido a la política de los arzobispos de Toledo si bien el concejo supo siempre mantener una serie de prerrogativas y privilegios "de uso y de costumbre" que casi ningún prelado osó contravenir ${ }^{14}$. Aunque éstos tenían el derecho de intervenir directamente en todos los asuntos locales, Talavera se apresuró a salvaguardar sus costumbres, privilegios, franquezas y libertades mediante unas capitulaciones asentadas entre la villa y el arzobispo Gómez Manrique en octubre de ese mismo año de $1369{ }^{15}$.

A la larga esta medida supuso una especie de victoria del concejo sobre el poder señorial, pues de esa forma, quedaban limitadas las competencias del prelado en la villa. Las capitulaciones podrían inter-

13 El privilegio enriqueño está firmado en Toledo el 25 de junio de 1369, y existe confirmación en las Cortes de Toro de 1371. Vid. Gómez Menor, op. cit., p. 61 y ss.; J. A. García LUJÁN: “Expansión del régimen señorial en la región toledana bajo Enrique II: Talavera de la Reina e Illescas" en Anales Toledanos, XIV (Toledo, 1982), pp. 84-89.

14 De todas formas la política intervencionista de prelados como Jiménez de Cisneros en su etapa al cargo del arzobispado de Toledo (1495-1517) supusieron un iranco retroceso en este pulso político entre concejo y señor. (César PACHECO. El Sínodo de Talavera de 1498 y la relación de Cisneros con la Villa. Conferencia leída el 28-X-98 en la UNED de Talavera. Inédito.)

15 SuÁrez Álvarez, op. cit., 176. D. Juan de Cerezuela o Juan de Luna, arzobispo de Toledo entre 1434 y 1442 confirmó los privilegios y capitulaciones por los prelados anteriores Gómez Manrique, Pedro Tenorio, Pedro de Luna, Sancho de Rojas y Juan Martínez de Contreras (Archivo Diocesano de Toledo, Libro $1.465 \mathrm{~m}$ fols. 52-53). 
pretarse como una especie de resistencia concejil, eso sí, pacífica frente a otros fenómenos de movimientos antiseñoriales que se suceden en Castilla a raíz de la entronización de Enrique ${ }^{1}{ }^{16}$. Entre los puntos que se acordaban y que el prelado consintió se encuentra la designación de alcaldes, alguaciles y escribanos de entre los vecinos de la villa, como era de costumbre. La facultad del señor para designar cargos concejiles trasciende así la mera conveniencia del titular del señorío que podría elegir personas forasteras ajenas a la villa. En el caso de las regidurías, solían presentarse al señor una lista de candidatos propuestos por la villa sobre la que el señor decidía; en otras ocasiones era el propio prelado quien «imponía» a su propio regidor, afín a sus intereses ${ }^{17}$.

Pero ¿cómo era la Talavera de la primera mitad del siglo XVI, cuando el reinado de Carlos I estaba en su pleno apogeo? Debemos decir, en principio que esta villa de señorío con un gran territorio bajo su control despunta entonces como un emporio económico y demográfico. Entre los rasgos definitorios de esta época hay que destacar la permanencia de elementos propios de la sociedad medieval que se perpetúan más allá del cambio de siglo trascendiendo múltiples manifestaciones de la vida social y política del momento. Pero también parecen vislumbrarse algunos cambios físicos, sobre todo en lo que respecta a la arquitectura y el urbanismo ${ }^{18}$, que indican un considerable grado de asunción de referentes introducidos en el primer renacimiento español, o al menos con un esfuerzo por poner en práctica medidas y soluciones diferentes de las que hasta entonces se venían proponiendo.

Talavera va a experimentar en estas primeras décadas del quinientos una evolución asombrosa en el crecimiento y desarrollo del concejo; a pesar de un duro golpe demográfico con la epidemia de peste que se da en torno a $1507^{19}$, en los años posteriores ve aumentar su

16 Julio VALDEÓN, Los conflictos sociales en el reino de Castilla en los siglos XIV y xV. Madrid, 1986.

17 César PACHECo JiménEZ, “El regimiento en Talavera de la Reina en el siglo XV» en Cuaderna (Revista de estudios humanísticos de Talavera y su antigua tierra) n. ${ }^{\circ} 6$ (Talavera, 1998), pp. 44-53.

18 César PACHECo e Inés VALVERDE, “La transformación del espacio urbano de Talavera de la Reina en el siglo XV'»en Espacio, Tiempo y Forma, serie VII, n. 7 (Madrid, 1994), pp. 73-96.

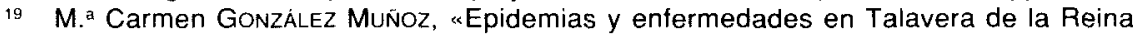
(siglos XVI y XVII) en Hispania, XXXIV (Madrid, 1974), pp. 149-168. 
población considerablemente llegando a un índice poblacional de los más altos de las villas de segundo orden de Castilla ${ }^{20}$. Sin duda, asistimos al despegue económico de una comunidad de villa y tierra, una villa con un extenso alfoz, un territorio desigual en cuanto a sus características físicas y a su distribución demográfica en el espacio. La carencia de vías de comunicación en amplias áreas de este territorio durante la Baja Edad Media empezaba a solucionarse modestamente en esta época, al amparo del surgimiento de nuevas aldeas y lugares, y la consolidación de otros núcleos de población que intentará establecer relaciones entre sí, tejiendo una red de caminos vecinales y comarcales que mejorarán la infraestructura viaria ${ }^{21}$, en cuya vigilancia y la de los despoblados tendrá un gran papel la San Hermandad de Talavera, que ya durante la el bajo medievo se había constituido como una institución policial de gran prestigio al servicio de una economía agropecuaria como la de la villa ${ }^{22}$.

La actividad comercial y artesanal, junto con el trabajo de la tierra y las huertas de cinturón periurbano de la villa, produciendo un volumen importante de productos agropecuarios para el consumo local de una población en franco crecimiento, marcaron coordenadas importantes en la vertiente económica. Una ciudad que sin duda marchaba por los mismos derroteros que las del resto de la Corona, trasluciendo en su interior una serie de contrastes típicos de la época: el desequilibrio entre el pueblo llano que sigue padeciendo los problemas seculares del sistema, y el cada vez más rígido control que las elites del poder van fraguando a partir del prestigio sociopolítico y la tenencia de un patrimonio importante. Un desajuste importante que además nos permite ver una doble vertiente: mientras que podemos calificar la época como la «Edad de Oro de Talavera», con manifestaciones humanísticas y personajes tan relevantes como Gabriel Alonso de He-

${ }^{20}$ M. $^{a}$ C. GonzÁlez MuÑOz, La población de Talavera de la Reina (siglos XVI-XX). Estudio sociodemográfico. Toledo, 1974.

21 C. PACHECO, "Infraestructura viaria y hospedaje en Talavera de la Reina. Siglos XVI y XVI!: erı Actas del II Cogreso Internacional de Caminería Hispánica. Madrid, 1996, t. II, pp. 385-411.

${ }^{22}$ Acerca de la Santa Hermandad de Talavera, pueden verser, entre otros, los trabajos de Araceli Gulllaume Alonso: Una institución del Antiguo Régimen: La Santa Herrmandad Vieja de Talavera de la Reina (siglos xvl y xvii). Talavera, Excmo. Ayuntamiento, 1995. Y Teresa Engenios MARTín, La Santa Hermandad de Talavera. Una institución de vigilancia y justicia en despoblados. Toledo, Caja de Ahorro de Toledo, 1992. 
rrera y sus hermanos, o el propio autor de La Celestina, Fernando de Rojas, que permanecería en nuestra villa como alcalde mayor desde 1508 hasta su muerte en $1541^{23}$, también puede observarse que la población del estamento bajo se mantiene en una generalizada situación crítica ${ }^{24}$.

La actitud del concejo ante los acontecimientos del reino no fue aséptica; es conocido el papel de apoyo que la villa tomó a favor del emperador y la corona en la revuelta de la comunidades, apoyo que el propio Carlos $V$ quiso agradecer con una carta enviada al ayuntamiento talaverano ${ }^{25}$. En ella se reconocía la lealtad al gobernador del arzobispado don Francisco de Mendoza, que además era consejero del monarca, en los difíciles momentos que sucedieron a la muerte del joven cardenal Guillermo de Croy en 11 de enero de 1521, cuando el arzobispado quedó vacante, y los comuneros forzaron a que el cabildo eligiese a un prelado adepto a su causa ${ }^{26}$, situación que se agravó con la llegada del obispo comunero Acuña

23 Inés Valverde AzUlA, «Documentos referentes a Fernando de Rojas en el Archivo Municipal de Talavera de la Reina" en Celestinesca, vol. 16, n. ii (noviembre, 1992) y de la misma, «Fernando de Rojas, alcalde y hombre de letras" en Talavera en el Tiempo. Talavera, Excmo. Ayuntamiento, 1994.

${ }^{24}$ Para conocer todos estos aspectos de forma pormenorizada y más bibliografía vid la obra colectiva de C. PACHECO y otros, Un autor, una ciudad, un tiempo. Fernando de Rojas y la Talavera del siglo xvi. Talavera, Colectivo Arrabal, 1999.

25 La carta está fechada en Worms, a 18 de mayo de 1521: "Conçejo, Justiçia, Regidores, cavalleros, escuderos, ofiçiales y omnes buenos de la villa de Talavera, asi por cartas de nuestros visorreyes y governadores desos reynos de don Françisco de Mendoça del mi consejo y governador dese arçobispado, como por otros que de alla me an escripto, he sabido en la paz y sosiego en que aveis estado despues del fallesçimiento del Reverendisimo Cardenal de Croy, arçobispo que fue desa Santa Yglesia de toledo, y la voluntad que aveis mostrado para me servir en los que por los dichos nuestros visorreyes y don Françisco aveis seydo rrequeridos, $y$ el ofreçimiento que hezisteis al dicho don Françisco para que se viniera a esta villa. Yo os 10 agradezco y tengo mucho en serviçio que bien aveis mostrado vuestra antigua lealtad. Asi vos mando y encargo lo continuéis estando durante mi breve absençia desos reynos como hasta aquí avéis estado en toda paz y sosiego y justiçia, y guardéis y cumpláis lo que por los dichos nuestros visorreyes o por el dicho don Françisco de Mendoça de mi parte vos fuere mandado. que en ello seré muy servido. $Y$ creed que de todo ello tengo y terné espeçial memoria para mandar mirar lo que a esta villa en general y a los veçinos della en particular, tocare, $y$ hazerlos toda la merçed que oviere lugar, como vuestros serviçios y lealtad mereçen". (Original en Archivo Municipal de Talavera; publicada una reproducción en la obra de Clemente Palencia, El Archivo Municipal de Talavera de la Reina. Talavera, Excmo. Ayuntamiento, 1959):

26 Fernando Martínez GIL, Toledo en las Comunidades de Castilla. Toledo, IPIET, 1981, p. 34. 
para controlara las rentas del arzobispado. El concejo talaverano ya había demostrado su recelo para participar en la causa comunera. En febrero de 1521 Toledo había solicitado de Talavera el envío de gente de a pie y de a caballo contra algunos nobles realistas de la comarca del priorazgo de San Juan ${ }^{27}$. La respuesta de Talavera fue claramente de evasivas, argumentando que necesitaban sus efectivos de soldados para la defensa de la villa; y llegaron a hacerse fuerte en la misma mediante el cierre de las puertas y el refuerzo de sus defensas y torres.

En aquella coyuntura asistimos a una de las manifestaciones de la tensión entre la villa de Talavera y su presunto señor a quien no reconocían, el obispo Acuña. El 4 de marzo se reunieron las parroquias y justicia y decidieron que no recibirían al prelado sin una bula papal autorizándole a tomar posesión del arzobispado; a finales del mes, sabiendo que Acuña había irrumpido en la catedral toledana, los talaveranos volvieron a cerrar las puertas y a establecer un férreo control y vigilancia, todo ello declarando su fidelidad al emperador; la tensión iba creciendo y el cabildo toledano llegó a advertir a Talavera de las intenciones del obispo, pero ésta se negó a reconocerle como gobernador y de paso, reforzó sus defensas y la colaboración de resistencia con la villa de Puente del Arzobispo, también leal al rey ${ }^{28}$.

Evidentemente, la actitud del concejo frente a las Comunidades se podría interpretar como un deseo de secundar la legitimación de la corona en estos acontecimientos tan complejos, pero también subyace un cierto empeño de autodeterminación de Talavera y sus oligarquías, sobre todo, ante el propósito comunero de Toledo. Y por lo que atañe al conflicto con el obispo, es notoria su intransigencia ante las injerencias de un "señor» de la villa que no hubiera concertado y reconocido los privilegios y costumbres que tan celosamente pretendian asegurar en la villa.

27 En sesión del ayuntamiento toledano de 6 de febrero de 1521 se encargaba a Juan Carrillo para que escribiese a Talavera solicitándolo.

${ }_{28}$ Fernando MARTinez GlL, La ciudad inquieta. Toledo comunera, 1520-1522. Toledo, Diputación Provincial, 1993, p. 224. Las noticias sobre los acuerdos del ayuntamiento talaverano sobre el asunto están recogidos en la obra de Alfonso DANVil.A: "Historia crítica y documentada de las Comunidades de Castilla" en Memorial Histórico Español. Madrid, Real Academia de ia Historia, 1897-1900, vols. XXXVI y XXXVIII. 


\section{LA POSESIÓN DE LA VILLA COMO EXPRESIÓN DE LAS RELACIONES FEUDALES}

La toma o posesión real y legal de la villa y su tierra por parte del prelado era un acto de gran trascendencia política, revestido de una significación simbólica relevante. Los signos feudales del «pleito y homenaje" así como el reconocimiento del señor por los poderes locales, justicia y regimiento, se articulaban en un desglose de representación ante el pueblo. Tomemos como ejemplo el acta de posesión que hizo el delegado del arzobispo Juan de Luna, el capellán del rey y abad de Alcalá la Real don Juan Alfonso de Cuenca, en $1439{ }^{29}$ :

"In dei nomine amen. Sepan quantos este público ynstrumentto vieren como en la villa de Talauera, jueues çinco dias del mes de mayo del nasçimiento de Nuestro Saluador leshu Xpristo de mill e quatroçientos e ttreinta e çinco años. Este dicho dia estando en el conçejo desta dicha villa que es çerca e junto con la torre de la eglesia collegial de Santa María desta dicha villa e estando en el presente en el dicho concejo el onrrado e discretto señor lohan Alfonso de Cuenca, capellán de nuestro señor el Rey, abad de Alcalá la Real, procurador e nunçio mensajero de Nuestro Señor lohan de Luna por la gracia de Dios arçobispo de Toledo, primado de las Españas, chaçiller mayor de Castilla e del concejo de nuestro señor el Rey. Et otrosi estando y presentes Ferrand Alfonso de Vargas alcallde mayor de la dicha villa e Diego López de Ayala e Juan de Velada e Juan Duque e Ruy Garçia e Juan de Vargas e Nuño Gomes bachiller e Alfonso Mendes de Toro que son de los dose cavalleros e escuderos regidores ofiçiales e omes buenos ....del concejo desta dicha villa e otrosi muchos de gente cristianos e moros e judios vesinos e moradores de la dicha villa...

«...luego el dicho Diego de Bargas procurador del dicho conçejo leuantóse en pie e tomo las dichas bula e carta del dicho señor Rey e poder del dicho señor arçobispo en la mano en pusolas ençima de su cabeça e dixo que el en nombre del dicho conçejo, alcalldes, alguasiles e caualleros e escuderos e regidores e ofiçiales e omes buenos de la dicha villa coo su procurador que obedeçía e obedeçió las dichas bulla e carta del dicho señor Rey e poder...con la mauor reverençia que podia...e en cunpliendo...rresçibian e rresçibieron por señor al dicho señor don Juan de Luna arçobispo de Toledo e al dicho abad en su nombre e le entragavan e entregaron la posesión e casy posesión de la dicha villa e su tie-

29 En Talavera, a 5 de mayo de 1435: Posesión de la villa de Talavera por el arzobispo don Juan de Luna o de Cerezuela. (Archivo Municipal de Talavera, Jurisdicción. Sig. 1012). 
rra e alcaçar e fortalesas e torres della el luego los dichos alcalldes e alguasil e caualleros e escuderos regidores ofiçiales (etc)..estando todos ayuntados en el dicho conçejo dixeron que dauan e otorgaruan e dieron e otorgaron todo su poder cunplido... a Juan Duque e a Ruy Garçia rregidores vesinos moradores en esta dicha villa que ende estauan presentes...amos a dos juntamente en nombre del dicho conçejo puedan faser e fagan público omenaje al dicho señor arçobispo e al dicho abad en su nombre como su procurador por la dicha villa como deuen faser pleito e omenaje vasallos a su señor ... Et luego Juan Duque e Ruy Garçía leuantaronse e fueron a donde el dicho señor abad estaua e juntaron amos a dos juntamente sus manos e metieronlas entre las manos del dicho señor abad. Et luego el dicho señor... en nombre del dicho señor arçobispo e por el poder a el dado dixo a los dichos Juan Duque e Ruy Garçia: Uos Juan Duque e Ruy Garçía por el poder a vosotros dado e otorgado por el dicho conçejo de la dicha villa de Talauera como omnes fijosdalgo e en nombre del dicho conçejo fasedes pleito e omenaje a mi señor el arçobispo de Toledo don Juan de Luna e a mi en su nombre como su procurador una e dos e tres veses una e dos e tres veses e una e dos e tres veses que el conçejo e alcalldes e alguasiles e caualleros $e$ escuderos regidores e ofiçiales e omes buenos de la dicha villa de Talauera e vosotros en su nombre tenuedes e guarderedes esta villa para el dicho señor arçobispo e donde vieredes e supieredes que se trata su .. e onrra de supersona e de la dicha eglesia de Toledo que seredes en ello e to ayudaredes e conplir e donde vieredes e supieredes que se trata mal e dapno e despreçio del dicho señor arçobispo o de sus rrentas e derechos que lo arrendiaredes a todo vuestro leal poder en quanto pudieredes en donde arrendar no lo puderedes que gelo facedes saber lo mas ayna que vosotros pudieredes por vosotros e por vuestros çiertos mensajeros e por cartas; e que lo acogeredes al dicho señor arçobispo en lo alto e en lo baxo con muchos o con pocos, de noche o de día...e pagado e que fueredes ...por su mandado guardando la realesa e subgeçión...e devedes al dicho señor Rey e a su altesa e señoría e a nuestro señor el prínçipe don Enrique su fijo e aquellas cosas e casos que en los derechos e fueros e ordenamientos de Castilla son espresados e que non rrevelaran los secretos del dicho señor arçobispo que los fuere dichos por su merçed e por sus cartas e mandado.

El qual dicho pleito e omenaje los dichos Juan Duque e Ruy Garcia por sy e en nombre del dicho concejo dixieron que fasian e fisieron en la manera que dicha es en manos del dicho abad en nombre del dicho señor arçobispo una e dos e tres veses ...según la costumbre de España, como omes fijosdalgo lo qual el dicho abad en el dicho nombre pedió por testi. monio. E luego el dicho abad en el dicho nombre usando de la posesyón de la dicha villa (puso a los oficios de alcaldes mayores y alguaciles mayores) e tomoles luego las varas que tenian en sus manos los dichos alcaldes e alguasiles e luego en continente el dicho abad dixo e preguntó a los dichos Ferrand Alfonso, etcc. que si les plasia de tener los dichos ofiçios e usar dellos por el dicho señor arçobispo como señor de la dicha 
villa e por el en su nombre... E luego el dicho abad rresçibió juramento en forma de () derecho sobre la señal de la crus e las palabras de los santos Evangellios que corporalmente taniern con sus manos que guardarán seruiçio del dicho señor arçobispo e que donde vieren su pro e onrra que de su persona e de la su eglesia de Toledo e de sus rentas(...)".

La plasmación del ceremonial, de una gran significación simbólica a la vez que política, conviene cotejarlo con el que se llevó a cabo en 1558 , con motivo de la toma de posesión de la villa por parte del delegado del prelado Carranza, don Diego Briviesca de Muñatones ${ }^{30}$ :

A la sesión de 21 de marzo de 1558 asistieron: Juan Prado de Bivar, corregidor. Gaspar Duque de Guzmán, Alvaro de Loaysa, Hernando Alvarez de Meneses, Gerónimo Cornejo y Pedro de Toro, regidores. Jusepe de Villarael, procurador general. Luis de Cepeda, Diego López de Ribadeneira, Juan Ramírez de Arellano y Alvaro Gutierrez, jurados. Alonso de Burgos y Juan de Sigüenza, escribanos.

Los señores justicia y regimiento de la villa de Talavera se juntaron en el ayuntamiento con el licenciado Briviesca de Muñatones, gobernador general del Arzobispado de Toledo, que anuncia que

"el llmo. Sr. Fray Bartolomé de Carranza y Miranda, arzobispo de la Santísima Yglesia de Toledo, le retiene su "Real Magestad" porque "tiene neçesidad de su persona para çierto efecto que del tiene "no pudo venir para tomar la posesión y enbia un poder a el y al llustre señor licenciado Mérida ${ }^{31}$ para tomar la dicha posesión desta villa y para que conste dello hizo demostraçión del poder ${ }^{32}$. Et ansy leydo el dicho poder el dicho señor licenciado Briviesca de Muñatones salió del dicho ayuntamiento y salido los dichos señores justiçia y regimiento platicaron sobre lo susodicho y mandaron bolbiese a entrar en el dicho ayuntamiento y estando dentro del dicho ayuntamiento se sentó en el lugar más pertinente del dicho ayuntamiento y pidió () nesçesario requirió a los dichos señores justiçia y rregimiento le manden dar la posesión desta dicha villa

30 Archivo Municipal de Talavera, Libro de Acuerdos 1558, sesión 21 marzo (fols. 114117). Acta de toma de posesión de la villa de Talavera por parte del delegado del arzobispo Bartolomé de Carranza, el licenciado Briviesca de Muñatones.

${ }^{31}$ Se refiere al ya citado canónigo de Palencia, don Pedro de Mérida.

32 El poder está firmado en Bruselas, a 15 de enero de 1558. En él se constataba el deseo del recién electo arzobispo de que Mérida y Briviesca tomaran en su nombre la posesión del dicho arzobispado así como poder decidir sobre cuestiones del gobierno del mismo hasta su llegada a la silla arzobispal. (Archivo Municipal de Talavera, Libro de Acuerdos de 1558, sesión de 21 marzo, fol. 114 v.) 
en nombre del Ylustrisimo señor don fray Bartolomé de Carranza y Miranda, arçobispo de la Santa Yglesia de Toledo y señor desta dicha villa y su tierra para el mesmo como el señor dello.

$Y$ luego el dicho señor Corregidor resçibió juramento del dicho señor licenciado Briviesca de Manatones y el puso la mano derecha en la cruz y le hizo por el nombre de Dios nuestro señor y por Santa María, su madre nuestra señora, $y$ por las palabras de los santos quatro evangelios de quieran questán escriptos (sic), en nombre de su señoría Ylustrísima por virtud del dicho poder, que su señoría Ylustrísima y el dicho señor licenciado Briviesca de Manatones, governador del dicho arçobispado, guardarán y cunplirán todos los previllegios y ordenanças, buenos usos y costumbres questa villa tiene según y como an sydo usadas y guardadas hasta aqui por los otros arçobispos pasados de buena memoria e por ello dixo que obligara e obligó los bienes propios y rentas de su ylustrísima por virtud de su poder.

(Que haga público omenaje): Y luego los dichos señores justiçia y rregimiento pidieron al dicho señor Briviesca de Muñatones que de más de juramento questá fecho haga público omenaje como cavallero hijodalgo según fuero de España en nombre de su señor de guardar y que su señoria ylustrisima guardará y cunplirá los dichos privillegios, hordenanças, buenos usos y costumbres questá dicha villa tiene.

Y luego el dicho señor lizenciado Briviesca de Muñatones dixo que estava presto de lo cunplir. Y luego el señor Gaspar Duque de Guzmán, rregidor más antiguo del dicho ayuntamiento se levantó y ansy mismo el dicho licenciado Briviesca de Muñatones y levantado el dicho señor Gaspar Duque tomó entre sus manos las manos del dicho lizenciado Briviesca de Muñatones y por tres vezes le preguntó sy hazía público omenaje como cavallero hijodalgo en nombre de su señoría según fuero de España de guardar y cumplir los previllegios, hordenanças, buenos usos y costumbres que esta dicha villa tiene, el dicho señor lizenciado Briviesca de Muñatones rrespondió las dichas tres vezes que ansy lo juraba e juró e prometia y prometió en nombre de su señória de lo tener y guardar y cunplir como () se sigue y les está pedido por los dichos señores justiçia y rregimiento como cavallero hijodalgo.

Y fechas las dichas solenidades el dicho señor lizenciado Briviesca de Muñatones se tornó a sentar en su asyento y lugar y los dichos señores justiçia y rregimiento dixeron que le daban y dieron la posesyon desta dicha villa en nombre de su señoría Ylustrísima y le? Dixeron que rreconosçen y rreconosçieron a su señoría Ylustrísima por tal arçobispo de Toledo en la Santa Yglesia de Toledo, y señor desta villa y que así corno a tal señor le obedesçerán y guardarán y cunplirán sus mandamientos y provisiones según se an guardado y cumplido a los arçobispos de buena memoria y con esto el dicho señor licenciado Briviesca de $\mathrm{Mu}$ ńatones dixo que se daba e dio por contento de la dicha posesyón en 
nombre de su señoría y le pidió por testimonio la qual dicha posesyón tomó y los dichos señores justiçia y rregimiento le dieron quieta y pazificamente syn contradizión alguna. Pasó ante nos los dichos escrivanos. Juan de Siguença, escrivano".

En estas actas se trasluce el antes aludido empeño de la villa y sus instituciones por conservar los privilegios, usos y costumbres frente las posibles injerencias del señor. Se acentúa por ello, en el reconocimiento del legítimo dueño y señor jurisdiccional de la villa, la voluntad de que el delegado arzobispal haga a la vez su pleito y homenaje de guardar esos privilegios y ordenanzas. Un aspecto que nos ilustra gráficamente ese pulso político entre la villa y el señor. Pero podríamos preguntarnos si en estos actos se da una verdadera feudalización interna del señorío arzobispal sobre la villa de Talavera.

La cuestión del feudalismo medieval en España ha sido objeto de profundas polémicas en las cuáles no entraremos aquí; definir nuestro marco de referencia teórico nos lleva a utilizar el término feudalismo más allá del sentido institucional de esas relaciones feudovasalláticas. En palabras de Julio Valdeón, "si nuestro punto de vista se sitúa en el campo de los que definen el feudalismo como sistema social cabe decir que al concluir la Edad Media la feudalización de los reinos hispánicos era plena. El robustecimiento del poder monárquico en tiempo de los RR CC. no sólo no puso en peligro las estructuras económicas y sociales existentes, sino que las consolidó. La posterior evolución hacia la monarquia absoluta fue perfectamente compatible con la estructura feudo-señorial» ${ }^{33}$.

Lo que se plantea a la hora de enfocar un fenómeno feudal tardío en la España del siglo XVI es la vigencia o no de la institución y de las relaciones sociales entre el señor y los vasallos. Lo que se encuentra no obstante, al margen de postulados teóricos de si hubo o no una verdadera feudalización de territorios y gentes en nuestro pais, son realidades con un sistema de relación con muchos elementos feudales, de herencia medieval tanto de corte española como francesa. La pervivencia pues de esas fórmulas, que aparecen en la abundante documentación del siglo xvı, obliga a considerar al menos una coexistencia en esos términos de monarquía/señorio/relaciones feudales.

33 Julio VALDEÓn, El Feudalismo. Madrid, 1992, pp. 148-149. 
Habría que analizar cada caso pormenorizadamente para ver hasta qué punto es indicativo del mantenimiento de la fórmula feudovasallática la aparición de esos elementos como «vasallaje», "pleito-homenaje», claúsula de "guerra y paz", etc. en las fuentes ${ }^{34}$; en los ámbitos urbanos, a fines del siglo xv también se utilizaron las viejas fórmulas a la hora de rendir el vasallaje a los señores de la alta nobleza, fenómeno que puede trasladarse en el caso de otros señoríos como los de abadengo o eclesiásticos ${ }^{35}$.

\section{LA CEREMONIA DE LA POSESIÓN Y SUS SÍMBOLOS}

Lo que encontramos en el caso de Talavera, comparando las fórmulas empleadas en las tomas de posesión de la villa del siglo xv con las de 1558 es que se da una pervivencia del ceremonial en gran parte. Empleando símbolos propios del feudalismo de tradición medieval: así por ejemplo, la costumbre del homenaje es la expresión más clara del vínculo vasallático mediante el convenio (placitum, pleyto), y el juramento de fidelidad al señor, lo que en España se llamó durante toda la Edad Media y posteriormente, como estamos viendo, "pleyto y homenaje» ${ }^{36}$.

Esto se concreta materialmente según la documentación analizada en el acto de la mezcla de manos, la immixtio manuum, símbolo empleado tanto en Castilla, como en León y Aragón; en ellas los representantes del concejo introducen sus manos entre las del señor o delegado, en los casos talaveranos, mientras realizan los juramentos de fidelidad al señor y a sus intereses. Esta modalidad de homenaje asegura Valdeavellano que es de influencia franca, mientras que en España era más habitual el conocido «besamanos", por el cual el vasallo besaba la mano del señor.

En las ceremonias de Talavera, esta última fórmula también se emplea; en ura sesión de ayuntamiento preparatoria para la recepción

\footnotetext{
34 Alfonso M.a GuILARTE: El Régimen Señorial en el siglo xvi. Valladolid, Secretariado de Publicaciones de la Universidad, 1987, p. 31.

35 María Asenuo GonzAlez, "Las ciudades" en José Manuel Nieto Soria (director): Orígenes de la Monarquía Hispánica: Propaganda y legitimación (ca. 1400-1520). Madrid, Dykinson, 1999, p. 127.

36 Luis G. De Valdeavellano, "Las instituciones feudales en España", apéndice en la obra de F. L. GANSHOF: El Feudalismo. Barcelona, Ariel, 1963, p. 249.
} 
del arzobispo Carranza, se mandaba que "por su antigüedad vayan en orden todos los cavalleros desta casa con la justiçia y besen las manos de su señoría y que el procurador general y jurados y letrados escrivanos e mayordomos vayan al resçibimiento como ofiçiales desta casa» ${ }^{37}$. Un orden que exigía la total representatividad de los órganos de gobierno locales, tanto los de índole política, ejecutiva y judicial.

Sin embargo otros componentes de este despliegue de los efectivos del concejo ante la recepción del señor son dignos de mención, por configurar un interesante cuadro de ese universo simbólico de las relaciones feudales entre el titular del señorio y la villa y su tierra. Analizaremos algunos de ellos que requiere una singular atención.

El arzobispo de Carranza, como hemos visto, no se presentó directamente en la villa cuando le correspondía llevar a cabo la toma de posesión, pocos días después de que el 8 de marzo de 1558 los dos delegados, Mérida y Briviesca, ocuparan en su nombre la mitra toledana. Para ello firmo un poder en Bruselas a nombre de ambos representantes que le representarían en estos actos oficiales. Pero, a partir de agosto de ese mismo año tenemos constancia de que Carranza ya se encontraba en España.

Los últimos días de septiembre los debió de pasar en Jarandilla, pues allí recibe a algún emisario del consistorio talaverano. Después de la muerte del emperador y de celebrar sus honras, a principios de octubre emprende viaje a Toledo, sede de su prelatura. En el camino es cuando pasa por Talavera y tendrá lugar el recibimiento y posesión personal de su villa de Talavera ${ }^{38}$. Si bien el licenciado Briviesca ya había hecho en su nombre el ceremonial institucional de la misma, podemos decir que es entonces cuando, por medio de su entrada por la ciudad, y después de las condiciones presentadas por el regimiento y justicia de la villa, hace efectiva esa posesión. Con esto, el ritual del acontecimiento se reviste de un alto valor de consenso mutuo entre ambas partes.

\footnotetext{
37 Archivo Muncipal de Talavera, Libro de Acuerdos de 1558, sesión 17 de septiembre, fol. $206 \mathrm{r}$.

38 Desgraciadamente se ha perdido el Libro de Acuerdos que empezaba el 29 de septiembre de 1558 y terminaba el 28 de septiembre de 1559, lo que nos impide conocer con exactitud la fecha de entrada en la villa y otros pormenores del acontecimiento. No obstante, hemos pretendido suplir esa falta de información con las noticias previas que el libro de 1558 nos ofrece, así como las referencias de otras crónicas locales.
} 
Los elementos que se ponen en juego entonces para el desarrollo de las funciones tienen mucho que ver con la transformación de la ciudad y con una participación colectiva de la comunidad, tanto de los vecinos como de las autoridades. Los preparativos previos a la recepción son interesantes y vienen reflejados en los libros de acuerdos del ayuntamiento talaverano.

a) La ciudad y su adecuación al recibimiento: como si de una fiesta grande se tratase el consistorio velará porque el aspecto cotidiano del paisaje urbano cambie ante la llegada del señor de la villa, tal y como se solía hacer en cualquier evento festivo, adecuando al protocolo el espacio público, transformándolo al menos externamente, en un despliegue escenográfico ${ }^{39}$. Las medidas que toma el ayuntamiento talaverano en esta ocasión van encaminadas a decorar las calles, la limpieza de las mismas, y la presencia de luminarias durante las noches de permanencia del prelado en la villa ${ }^{40}$.

Igualmente se ejecutan obras en algunos elementos del urbanismo; la Puerta de Cuartos, el acceso más importante a la ciudad por el oeste, es decir, desde el camino procedente de Extremadura, tenía una significación especial pues tradicionalmente era donde se efectuaba el juramento de los prelados antes de entrar en la villa. Esta puerta había sido abierta en torno a la primera mitad del siglo XII en un tercer recinto amurallado de Talavera, que acogía uno de los arrabales conocido como Arrabal Viejo durante la Baja Edad Media ${ }^{41}$.

El regimiento acuerda entonces, como preparativo de la entrada del prelado Carranza, llevar a cabo una serie de reformas en la puerta:

39 C. PACHECO: "Fiesta y ciudad en Talavera de la Reina el Antiguo Régimen: Aspectos de la instrumentalización del espacio urbano en las fiestas" en Espacio, Tiempo y Forma, serire IV, $n .{ }^{\circ} 10$ (Madrid, 1997), pp. 295-318.

40 Archivo Municipal de Talavera, Libro de Acueróos de 1558, sesión de 17 de septiembre, fol. $206 \mathrm{r}$.:

"Que se pongan çien hachones para se pongan luminarias por las calles donde se suelen poner y para los fazer los encargaron a Juan Martínez jurado y lo que costare se mande librar y que los haga poner y lo mismo encargaron a Alvaro Gutierres jurado y que hagan limpiar las calles.

- Mandóse que se pregone que todas las personas tengan luminarias la noche que su señoría ylustrisima entrare a esta villa sus puertas e ventanas so pena de dozientos maravedís e que las calles estén linpias e sin tinajas so la dicha pena..."

41 Sobre este barrio véase nuestra obra El Barrio de la Puerta de Cuartos: Historia social y cultural. Talavera, 1993 . Sobre la puerta de la muralla nos ocupamos en nuestro reciente 
"tratóse que se adereçe la puerta de Quartos para que entre por ella su Ylustrísima Señoria y que se ponga un escudo con las armas de su Señoría Ylustrísima y otros dos a los lados desta villa... y manden fazer puertas nuevas...» ${ }^{42}$. E 7 de septiembre se aprobó destinar 600 reales a dicha obra. También se acordó construir un arco en dicha puerta: "Encargóse al dicho Señor Álvaro Çervantes que provea de un arco para questé a la Puerta de Quartos al tiempo que su señoria entrare... y 10 que costare el arco se mande librar" ${ }^{43}$.

La puerta adquiere así un sentido simbólico de gran trascendencia convirtiéndose en Arco Triunfal, el primero y más importante, de otros que podrían colocarse en el itinerario urbano, práctica común en las entradas triunfales de la época ${ }^{44}$. La Puerta de Cuartos como escenario del juramento y de la posesión efectiva de la villa reúne en sí un protagonismo inusitado, expresión arquitectónica y política del orgullo local y manifestación de su fortaleza.

b) Elementos festivos complementarios: entre éstos figuran la contratación de ministriles o músicos que se situaron encima de la referida puerta en el momento de la ceremonia y entrada del prelado, según se expone en el acuerdo del 17 de septiembre.

c) Elementos oficiales del ceremonial. En 22 de agosto, sabiendo el ayuntamiento que fray Bartolomé de Carranza se hallaba en Valladolid

trabajo Las antiguas puertas de Talavera. Estudio histórico y arqueológico. Talavera, Excmo. Ayuntamiento, 2001.

42 Libro de Acuerdos 1558, sesión 31 de agosto, fol. 193 r. Según las noticias históricas que tenemos en esta obra de ampliación y remodelación de la puerta se colocaron tres escudos encima del arco que actualmente se conservan en la pared del testero de la ermita de Nuestra Señora del Prado de Talavera; uno representando una torre albarrana, otro con dos toros, ambos símbolos heráldicos del escudo de la ciudad, que en esta época se solian colocar por separado, y en el centro se ubicó un escudo arzobispal que según la tradición era de Carranza; sin embargo los elementos que aparecen en este escudo cuartelado no son plenamente identificables con el que usaba el prelado. Pensamos más bien que puede tratarse de una variante de la representación herádica de sus armas, caracterizadas por torres y lobos (Ventura Leblic GaRcia: “La heráldica arzobispal toledana" en Toletum, n. ${ }^{\circ} 23$ (Toledo, 1989), pp. 9 y ss.), junto a los atributos heráldicos del delegado arzobispal que tomó posesión de la villa en su nombre, el licenciado Briviesca de Muñatones, en el cual se dan 5 panelas dispuestas en sotuer (Fdo. GonzÁlez-Doria: Diccionario heráldico y nobiliario de los Reinos de España. Madrid, 1987, p. 660). Así tenemos en el $1 .^{\circ}$ cuartel una torre de sable y en el 2. aparecen dos posibles lobos junto a un árbol; en el $3 .^{\circ}$ es dificil su identificación, teniendo el $4 .^{\circ}$ las referidas 5 panelas del apellido Muñatones.

43 Libro de Acuerdos 1558, sesión 17 de septiembre, fol. $205 \mathrm{v}$.

44 FCO. Javier PIZARro Gómez, "La entrada triunfal y la ciudad en los siglos XVI y XVIII en Espacio, Tiempo y Forma, serie VII, n. 4 (Madrid, 1991), pp. 121-134. 
desde el día 10, se optó por consultarle a través de uno de los regidores que se hallaba en aquella ciudad por asuntos de pleitos en la Chancillería, y saber si ante su futura venida a Talavera era su "voluntad sy rreçibirá merçed en que se faga en esta villa fiesta o si terná voluntad no se fazer'. El 25 se leía en el consistorio una carta del prelado agradeciendo la actitud del ayuntamiento y notificaba que en breve pensaba ir por la tierra talaverana. En la referida sesión del 17 aparecen siguientes menciones "para tratar como su Ylustrísima Señoría (que estaba en Jarandilla) entrará para ver lo que se a de faser en su resçibimiento". Todas las autoridades debían someterse al protocolo de tal manera que cometen al señor Corregidor e al señor Diego de Montenegro rregidor, para que conbiden a todos los cavalleros e hijosdalgo para que salgan a rresçibir a su señoría y se aperçiban de cavalgaduras para ello". Y además que por su antigüedad vayan en orden todos los cavalleros desta casa con la justiçia y besen las manos de su señoría y que el procurador general y jurados y letrados escrivanos e mayordomos vayan al resçibimiento como ofiçiales desta casa.

En definitiva, los representantes del poder ejecutivo y político como garantes de los intereses del concejo debían articular su presencia de forma ordenada y de acuerdo a un plan protocolario, en el cual tenía la máxima responsabilidad el regidor más antiguo del ayuntamiento, que en esta ocasión era don Gaspar Duque de Guzmán. Se acuerda que éste en nombre de la villa pida el juramento a su señoría a la Puerta de Quartos que es por donde a de entrar conforme a la costumbre desta casa.

Al prelado al llegar a Talavera se le hacía una demostración del celo con que en la villa se guardan sus instituciones, privilegios, ordenanzas, usos y costumbres, una demostración sin duda cargada de gran significación política, para lo cual se le mostraba el libro de acuerdos y la forma en que los señores de la villa anteriores solían jurar ${ }^{45}$.

Igualmente, en señal de acatamiento, reconocimiento de la autoridad señorial el concejo, una vez que el prelado hacía su juramento de guardar las referidas condiciones en esta relación feudovasallática, se

45 Archivo Municipal de Talavera, Libro de Acuerdos 1558, sesión 25 de septiembre, fol. 211 r.: "Acordóse que se lleve el libro de ayuntamiento para que su señoría vea la solenidad de juramento que los prelados hazen la primera entrada en esta villa para que su señoría ylusirísima le constte dello..." 
le agasajaba con un "presente", regalo que pasaría a disfrutar algún regidor o justicia si el homenajeado no lo recibía. En los acuerdos tan sólo se menciona la adquisición del mismo sin indicar exactamente de qué naturaleza era. En la sesión del 27 de septiembre se menciona un libramiento de cierta cantidad de maravedís para ayuda a adquirir un presente para su señoría: "Proveyóse para que el próximo día de ayuntamiento se trate quien a de dar el presente a su señoría y quien 10 a de beneficiar sy su señoría no lo rresçibiere.." ${ }^{46}$.

\section{LA COYUNTURA DE LA POSESIÓN: LA MUERTE DEL EMPERADOR Y SUS HONRAS EN LA VILLA}

Todo el proceso de la toma y posesión de la villa de Talavera por el arzobispo Carranza y sus delegados estuvo marcado por unos acontecimientos coincidentes que van a revelar, sin embargo, aspectos de esa misma relación entre señor y vasallos. La muerte del ex emperador en Yuste como no podía ser de otra manera fue tratada en el regimiento talaverano en la sesión del 25 de septiembre y en la del 27 se siguieron tomando algunos acuerdos al respecto de las honras y los lutos que debian hacerse en la villa:

"E luego el señor Rodrigo de Carrança rregidor hizo rrelaçión a este ayuntamiento de lo que avía tratado con el arçobispo de Toledo nuestro señor sobre la muerte de su magestad.

E luego los dichos señores aviendo platicado sobre los suso dicho acordaron que en bien que se hagan honrras en esta villa por su magestad a los quales se llamen todos los hórdenes de frayles y cofradias y se hagan las honrras en la yglesia mayor las quales se comiençan el domingo en la tarde $y$ el lunes de mañana o antes o después quando su señoría mandare.

Que se haga para las dichas honrras un bulto donde se ponga las hachas e çera que se acordare poner al paresçer del cavallero desta casa que se cometiere.

Sobre los lutos se acordó se diese parte a su señoría yllma. Y que fuere a comunicarlo con el el señor Rodrigo de Carrança rregidor y le diere parte de cómo otras vezes se a fecho en esta villa por las personas rreales y de la nesçesidad questa villa tiene

46 Ibídem, fol. $216 \mathrm{r}$. 
Acordóse que se faga tañer por la muerte de su magestad las cam panas desta villa los quales se tengan esta novhe después de la oraçión y encargóse a Jusepe de Villarroel para que faga tañer.

Encargóse a Jusepe de Villarroel procurador general escriba (a) las hórdenes de frayles para que se hallen personas quando se hizieren las honrras.

Encargóse a Alonso e Juan Martínez jurados (que avisen a )...las cofradias para este dicho día. Encargóse al dicho Jusepe fable con los frayles de las dichas hórdenes para que el dia que se fizieren las onrras digan missa en la yglesia mayor cada çaçerdote y dichas traygan memoria de las que an dicho para questa casa se las mandará pagar.. ${ }^{47}$.

E Luego el señor Rodrigo de Carranza rregidor dio una carta de su señoría YIllma. que embyo a este Ayuntamiento se mandó leer y leyda dio quenta de lo que avie comunicado con su señoría yllma. Eluego los dichos señores mandaron que la carta que escrivió su S. ${ }^{a}$ Yllma. se escriva en este libro:

"Magníficas señorías, Rodrigo de Carrança nos comunicó la duda que alli se avía ofreçido sobre los lutos y a nos expresado que la nesçesidad de los propios de essa nuestra villa no de lugar a que se pueda sacar dellos todo el gasto de las onrras del emperador pero pues estamos obligados a fazer semejantes demostraziones por ser Rey propio conviene? Tomar los medios de menos...y no me parese mal el que allase ..que a tomar los lutos bajos por que suelen ser testimonio de mayor tristeza, y si con todo esto fase mucha costa para la comunidad y al presente no pudiere provello todo pareçenos que convenia que se partiere la costa de por medio entre los rregidores y los propios por lo que en semejantes casos están obligados los çibdadanos a socorrer la nesçedad de su republica y por que asu esta como en lo que toca al rrexçibimiento nuestro e nos comunicado con Rodrigo de Carrança lo que non conviene que se faga en todo momento de rremitirnos...?

E Luego los dichos señores acordaron que den lutos por las onrras de su magestad y que no se saque de veynteno arriba ni de diez e ocheno abajo lo qual se acordó atentos a la carta de sus señoría yllma. y la quenta que el señor Rodrigo de Carrança dio de lo que avie comunicado con su señoría yllma. y que los dichos lutos saquen a costa de los propios desta villa porque syempre que se an dado lutos an sydo a costa de los propios todos ellos y se hallan algunos yncovenientes de pagar la mitad las personas... dar los dichos lutos enteros de paños bajo a la mitad siendo paños finos.

Cometióse para que se saquen los dichos lutos a los señores Gaspar Duque de Guzmán e Alvaro de Çervates de Loaysa rregidores para que justamente con el señor corregidor lo saquen a los presçio e pagos que los paresçiere y lo que costare desde agora se les da poder...para que

47 Ibídem, sesión 25 de septiembre, fols. 210 y 211 . 
los puedan pagar librar en el mejor presçio de los propios que tiene esta villa.

Acordóse que los dichos lutos se den a justiçia e rregimiento (y demás autoridades...) e a dos hombres que an de tener cargo de la çera se les de a cada uno su capirote e caperuçejo y los dichos lutos se den a la persona que se hallare presente a las dichas onrras e sy alguna persona lo oviere llevado y no se allare presente a las onrras que lo pierda e lo vuelva.

Que el señor Francisco de la Rúa regidor se junte con el señor corregidor para faser el aposento ${ }^{48}$.

Como en otras ciudades, caso de Toledo que hizo sus más lucidas honras fúnebres por el emperador en el mes de noviembre, cuando el arzobispo Carranza se encontraba ya en su sede ejerciendo sus labores como titular de la mitra ${ }^{49}$, en Talavera vemos como la cuestión de los lutos suponía un desembolso importante para las arcas del concejo. Pronto los regidores y justicias se apresuraron a proponer la fórmula tradicional para sufragar este tipo de gastos, a costa de los propios; sin embargo, la propuesta cuando llegó al entendimiento del arzobispo, como señor que era de la villa, estimaba más correcto, y de acuerdo con que los lutos bajos, de paños y vestimentas, eran una buena demostración del duelo para con el difunto monarca, que si todo ello suponía un gasto superior que los regidores aportaran una parte y la otra se sacara de los propios de la villa.

La medida "sugerida" por el arzobispo no debió de agradar al regimiento, que en su empeño de mantener sus privilegios de clase y en contra de una mengua de sus patrimonios, acordaron sin más el cargar en las rentas del Puente del Alberche, sobre cuyo portazgo tenía la villa su jurisdicción, el importe de los lutos: los trajes, caperuzas y capirotes, etc. Si una cuestión como ésta podía poner en evidencia las diferencias entre los cuadros políticos de la villa y el señor de la villa, como no surgirian otro tipo de fricciones en asuntos de más gravedad.

48 Ibídem, sesión 27 de septiembre, fol. 214 r. y v. En nota adjunta a esta sesión se escribía que a 2 de noviembre de 1558 se pagaron 78.448 maravedís de costa de los lutos cargados en el arrendatario de la Puente del Alberche, de los propios de la villa.

49 Sobre las funciones de luto de Toledo véase la interesante relación que se hace en la $M e$ moria de las honras que se hicieron en esta cibdad de Toledo, por la muerte de el Emperador Don Carlos Nuestro Señor, que en el Gloria. Año 1558. En Relaciones Históricas de los siglos XVI y XVII. Madrid, Sociedad de Bibliófilos Españoles, 1896, pp. 42 y ss. Sobre el luto en la época vid. Fernando Martinez GiL, Muerte y sociedad en la España de los Austrias. Madrid, 1993. 
De todo este cúmulo de factores se desprende, por tanto, que aunque se mantienen fórmulas institucionales de tipo feudal en las relaciones entre vasallos y señor en un ámbito de señorío eclesiástico, la especial coyuntura que se da en 1558 con la muerte del emperador, condiciona en parte el ritual de la posesión. La evolución de Talavera como villa y cabeza de un extenso y rico alfoz no se verá mediatizada por la intromisión de los prelados, antes bien, se asiste en algunos casos, como el sucesor de Carranza, el cardenal Quiroga, a una efectiva colaboración; pero siempre dejando patente la defensa de los intereses concejiles frente a las premisas señoriales de tipo feudal que los prelados pudieran imponer.

El de Carranza y la simbología del ceremonial analizada no son sino meros ejemplos de esa materialización del discurso oficial del poder señorial en pleno siglo XVI, que se ve contrarrestado en cierta manera con el persistente discurso del concejo aludiendo a sus antiguos y reconocidos privilegios. 